\author{
Н.Н. Аблажей \\ Е.Н. Наземцева ${ }^{*}$
}

Русский анклав в Китайском Алтае

В 1917 году: итоги колонизации русско-китайского приграничья

\author{
DOI: 10.31518/2618-9100-2020-4-6 \\ УДК 94(47):314
}

Выходные данные для цитирования:

Аблажей Н.Н., Наземцева Е.Н. Русский анклав в Китайском Алтае в 1917 году: итоги колонизации русско-китайского приграничья // Исторический курьер. 2020. № 4 (12). С. 67-86. URL: http:// istkurier.ru/data/2020/ISTKURIER-2020-4-06.pdf

\author{
N.N. Ablazhey \\ E.N. Nazemtseva*
}

\section{Russian Enclave in Chinese Altai in 1917: Results of Colonization of Russian-Chinese Borderland}

\author{
DOI: $10.31518 / 2618-9100-2020-4-6$
}

How to cite:

Ablazhey N.N., Nazemtseva E.N. Russian Enclave in Chinese Altai in 1917: Results of Colonization of Russian-Chinese Borderland // Historical Courier, 2020, No. 4 (12), pp. 67-86. [Available online:] http://istkurier.ru/data/2020/ISTKURIER-2020-406.pdf

Abstract. The article introduces into scientific circulation the Report of Moshkin who was an employee of the Consulate of the Russian Empire in Shara-sume and an ensign of the Siberian separate mortar artillery battery. Moshkin reports about his trip to nine Russian villages located near the Russian-Chinese border in the Altai district of the Chinese province of Xinjiang in AprilMay 1917. The trip was carried out in connection with the need to put the population under loyalty oath to the Provisional Government. At the same time, there was a task to assess the number and religious composition of Russian colonists, their financial status and the international situation in the region. The report was deposited in the collection entitled "Chinese Desk. 1914-1917" (No. 143) of the Archive of the Foreign Policy of the Russian Empire. The introductory article and comments on the document provided a brief history of the agrarian colonisation of the Ili region by Russian immigrants and the mass resettlement of Kazakhs, which were of a spontaneous nature. The Altai district constituted a natural extension of the Semipalatinsk region geographically and ethnographically, and opened up access to trade and economic influence of Russia over Western Mongolia and Xinjiang. The Chinese side was inclined to regard the migrations of Kazakhs and the resettlement of Russians in Xinjiang as an increase of the Russian influence. The Russian enclave in the Chinese Altai existed until the mid-1960s. Those Russians who lived there tried to maintain a traditional and separate way of life in spite of both foreign policy and domestic political events.

Keywords: China; Xinjiang; Russian diaspora; Old Believers.

The article has been received by the editor on 21.05.2020.

Full text of the article in Russian and references in English are available below.

Аннотация. Публикация вводит в научный оборот Отчет сотрудника консульства Российской империи в Шарасумэ, прапорщика Сибирской отдельной мортирной артиллерийской батареи Мошкина о поездке в апреле-мае 1917 г. по девяти русским поселкам, расположенным вблизи русско-китайской границы на территории Алтайского округа китайской провинции Синьцзян. Поездка была осуществлена в связи с необходимостью приведения населения к присяге на верность Временному Правительству, одновременно ставилась задача

\footnotetext{
* Аблажей Наталья Николаевна, доктор исторических наук, Институт истории Сибирского отделения Российской академии наук, Новосибирск, Россия, e-mail: ablazhey@academ.org

Ablazhey Natalia N., Doctor of Historical Sciences, Institute of History of the Siberian Branch of the Russian Academy of Sciences, Novosibirsk, Russia, e-mail: ablazhey@academ.org.

Наземцева Елена Николаевна, доктор исторических наук, Научно-исследовательский институт военной истории, Военная академия Генерального штаба ВС РФ, Москва, Россия, e-mail: elenanazz@mail.ru

Nazemtseva Elena N., Doctor of Historical Sciences, Military History Institute, Military Academy of the General Staff, Russian Armed Forces, Moscow, Russia, e-mail: elenanazz@mail.ru
} 
оценить численность и конфессиональный состав русских колонистов, их материальное положение и межнациональную ситуацию в регионе. Отчет отложился в фонде «Китайский стол. 1914-1917 гг.» (№ 143) Архива внешней политики Российской империи. Во вводной статье и комментариях к документу приводится краткая история аграрной колонизации русскими переселенцами Илийского края и массовых переселений казахов, носивших стихийный характер. Алтайский округ составлял в географическом и этнографическом отношении естественное продолжение Семипалатинской области, открывал России доступ к торгово-экономическому влиянию на Западную Монголию и Синьцзян. Китайская сторона была склонна расценивать откочевки казахов и переселение русских в Синьцзян как усиление русского влияния. Русский анклав в Китайском Алтае просуществовал вплоть до середины 1960-х гг. Проживавшие здесь русские пытались сохранить традиционный и обособленный уклад жизни вопреки как внешнеполитическим, так и внутриполитическим событиям.

Ключевые слова: Китай; Синьцзян; русская диаспора; старообрядцы.

Данная публикация продолжает тему истории русско-китайского приграничья, поднятую авторами ранее ${ }^{1}$. Приграничные территории Русского и Китайского Алтая в Центральной Азии, так же как и Русское Трехречье на Дальнем Востоке, являются одной из важных контактных зон между двумя странами. Несмотря на то, что на протяжении длительного времени эти территории играли большую роль в русско-китайских отношениях в целом и в развитии двусторонних контактов в регионе в частности, тема русской колонизации Алтайского округа провинции Синьцзян редко поднималась в научных исследованиях. Отдельные его аспекты затрагивались при изучении проблем международных отношений и эмиграционных процессов в регионе, а также при изучении русского старообрядчества в Китае 2 .

Публикуемый документ из фонда «Китайский стол. 1914-1917 гг.» (№ 143) Архива внешней политики Российской империи представляет собой отчет прапорщика артиллерии Мошкина ${ }^{3}$, прикомандированного к российскому консульству в Шарасумэ военнослужащего

\footnotetext{
${ }^{1}$ См.: Аблажей Н.Н., Наземцева Е.Н. «То, чего добивалось дореволюционное русское правительство, в 1920-е гг. совершалось стихийно» (к истории заселения Трехречья) // Исторический курьер. 2019. № 4 (6). Cтатья 5 . URL: http://istkurier.ru/index.php/2018-06-21-11-23-48/2019/vypusk-2019-4?fbclid=IwAR3S7SnvMmlbtjDEveVece ER8paXIJM-XPMMGVZunx3zEUNavfqzBc1wc (дата обращения: 03.05.2020).

${ }^{2}$ См., например: Аргудяева Ю.В. Старообрядцы на Дальнем Востоке России. М., 2000; Аргудяева Ю.В., Хисамутдинов А.А. Из России через Азию в Америку: русские старообрядцы. Владивосток, 2013; Гутин И.Ю. Динамика численности русского населения Синьцзян-Уйгурского автономного района (1949-2000 гг.) // Вестник МГИМО Университета. 2011. Вып. 3. С. 74-82; Попов А.В. Русская диаспора в Синьцзян-Уйгурском автономном районе Китая // Национальные диаспоры в России и за рубежом в XIX-XX вв.: сб. ст. М., 2001. С. 194-201; Хисамутдинов А.А. В поисках земли обетованной: русские старообрядцы из России через Азию в Америку. Владивосток, 2015. С. 22-25. URL: https://evols.library.manoa.hawaii.edu/handle/10524/48722 (дата обращения: 03.05.2020); Цутому Цукадо. Участие в войнах русских старообрядцев в округе Алтай (СиньцзянУйгурский автономный район КНР) // Международные Заволокинские чтения. Рига, 2016. Сб. 4. С. 520-530.

${ }^{3}$ Мошкин родился 19 апреля 1887 г. в г. Спасск Тамбовской Губернии. В 1907 г. окончил 1-ю гимназию г. Пензы. В 1907 г. был зачислен на юридический факультет Казанского университета, откуда в следующем году перевелся в Московский университет на тот же факультет. Окончил его в 1911 г. с дипломом 1-й степени. 20 января 1912 г. был зачислен младшим кандидатом на судебные должности при Московском Окружном Суде, где в течение первого года работал в 1 уголовном отделении, параллельно исполнял обязанности защитника от суда; в последующие годы службы исполнял обязанности помощника секретаря и секретаря Председателя Суда. 20 ноября 1915 г. по собственному желанию был переведен в Омскую Судебную Палату на должность Старшего Кандидата, т.к. стремился получить место Мирового судьи в Сибири. В середине декабря 1915 г. командирован в Прокурорский Надзор Барнаульского Окружного Суда, где в течение полутора месяцев исполнял обязанности участкового Товарища Прокурора, вплоть до призыва на военную службу, в качестве ратника 2 разряда. Призыв состоялся 13 февраля 1916 г., после чего был зачислен в г. Томск в Отдельную Сибирскую Запасную Мортирную Батарею, 9 января 1917 г., произведен в прапорщики. 18 февраля 1917 г. согласно распоряжению Заведующего Омским Артиллерийским Управлением, был командирован в полубатарею 4 батареи, выделенную из 11 Сибирской Стрелковой Артиллерийской Бригады и входящую в состав гарнизона крепости Шарасумэ в Китае. Затем после ходатайства консула перед Министром Иностранных дел был оставлен в Шарасумэ для усиления штатов Консульства. Дальнейшая судьба неизвестна Архив внешней политики Российской империи (АВП РИ). Ф. 143. Оп. 491. Д. 3253. Л. 10.
} 
Сибирской отдельной мортирной артиллерийской батареи, который по поручению консульства посетил девять русских поселений в Алтайском округе.

Илийский край был буферной зоной между двумя империями. Исторически здесь имелись поселения уйгуров и кочевья казахов. В 1871 г. в регион были введены русские войска, и в течение 10 лет он находился в составе Туркестанского военного округа. Россия вернула большую часть Илийского края Цинской империи по итогам подписания Ливадийского (1879) и Петербургского (1881) договоров. При образовании провинции Синьцзян в 1884 г. Илийский край получил статус отдельного военного округа. В 1905 г. из состава Кобдоского округа был выделен самостоятельный в административно-территориальном отношении Алтайский округ с центром в крепости, расположившейся на месте джунгарского монастыря Шарасумэ (ныне г. Алтай в СУАР КНР). Выделение округа было обусловлено массовым перемещением казахского населения, земельными спорами и невозможностью контролировать ситуацию из Кобдо.

Российское консульство в Шарасумэ открылось в мае 1911 г., и первым его консулом был назначен М. Кузьминский ${ }^{4}$ В те годы в регионе было очень неспокойно. Военно-политическая ситуация в очередной раз обострилась из-за входа в регион дунганских войск из соседнего Илийского округа, враждебно настроенных как к китайцам, так и русским. На российского консула было совершено покушение. Ответом России стал ввод в Шарасумэ в сентябре 1913 г. русского отряда. Провозглашение независимости Монголии (Халхи) от Китая в 1911 г. усилило сепаратистские тенденции, которые шли в разрез с интересами Китая. Вопрос о демаркации между китайской и монгольской сторонами был урегулирован при участии России в декабре 1913 г. Российский консул М. Кузьминский и главный управитель Северо-западного края, правитель Алтайского округа князь Палта Валт заключили двусторонний договор (без участия Монголии) о демаркации, согласно которому Алтайский округ отходил Китаю.

В отличие от границ, вопрос подданства части перемещенного населения между Китаем и Россией не был окончательно урегулирован. Количество казахского населения в регионе постоянно росло за счет массовой эмиграции из Степного края и Российского Туркестана. Откочевки казахов в Синьцзян в начале XX в. были спровоцированы в значительной степени аграрной политикой России, вызвавшей массовый приток переселенцев из Европейской России. Из-за восстания 1916 г. в регион хлынул поток беженцев. По данным российских консульских служб, численность беженцев в Илийском крае достигла 100 тысяч ${ }^{5}$. Их присутствие обострило межнациональную напряженность и усугубило экономические трудности в регионе.

За пределы империи мигрировали не только казахи, но и русские. Их число было незначительным, в основном речь шла о старообрядцах и казаках. Упоминания о первых русских поселенцах-старообрядцах относится еще к XVIII в. Первые русские поселения появляются здесь в 30-60-е гг. XIX в.; большинство переселенцев являлись старообрядцами часовенного и спасовского согласий. Первые свидетельства об этих поселениях есть у Пржевальского, упоминавшего, что первоначально они поселились близ озера Лоб-Нор 6 , но были изгнаны китайскими войсками ${ }^{7}$. Новым местом поселения стал высокогорный район около пресного озера Канас, расположенного в 30 км на юг от западного участка современной российскокитайской границы и стыка границ Казахстана, Китая, Монголии и России. Восточнее озера возникли два старообрядческих поселения: Ком (Хом) и Канас ${ }^{8}$. Жители этих поселений

\footnotetext{
${ }^{4}$ Кузьминский Михаил Николаевич - дипломат; студент Пекинской Миссии (1903-1904), секретарь и драгоман в Российском консульстве (1905, 1907-1910), в Улясутае (1906), в Харбине (1911). Российский консул в Кобдо (1912-1913) и в Шарасуме (1915-1917).

${ }^{5}$ АВП РИ. Ф. 143. Д. 448. Л. 146.

${ }^{6}$ Лобнор (Лоб-нор) - высохшее озеро в юго-восточной части Кашгарской (Таримской) равнины. Озеро постепенно уменьшалось и засолонялось вследствие хозяйственной деятельности человека. В $1964-1996$ гг. здесь размещался полигон ядерных испытаний, проведено 45 ядерных взрывов.

${ }^{7}$ Пржевальский Н.M. Четвертое путешествие в Центральной Азии. СПб., 1888. С. 317-319.
} 
вели изолированную жизнь вплоть до 1960-х гг., занимаясь мараловодством, земледелием, пчеловодством, рыболовством и охотой.

Новый приток русских в регион относится к периоду русской оккупации Илийского края, хотя наиболее активное переселение русских в Китайский Алтай зафиксировано на конец XIX - начало XX в., при этом российское правительство никак не содействовало переселенческому движению. К 1916 г. в Алтайском округе существовало уже девять русских поселков, где проживал 861 человек ${ }^{10}$. Притоку переселенцев способствовало наличие обширных угодий, слабость китайской власти и присутствие русских вооруженных сил и консульства в Шарасумэ и Бурчуме. Дело в том, что право приобретать землю и недвижимость в Китае русские получили по Петербургскому договору 1881 г., но это правило распространялось только на те города Китая, где располагались российские консульства. В округе Шарасумэ такая возможность официально появилась только в 1911 г., хотя русские фактории в Китайском Алтае появились намного раньше. Некоторые русские крестьяне, проживая на российской стороне, арендовали пашни и сенокосы за кордоном ${ }^{11}$.

Китайская сторона была склонна расценивать откочевки казахов и переселение русских в Синьцзян как усиление русского влияния. По данным В.В. Галиева, Россия настолько укрепилась в Синьцзяне, что «вскоре в регионе фактически стали существовать две власти местные китайские и российские консулы», причем это касалось не только внешней политики, но и торговли, и заселения края русскими подданными ${ }^{12}$. Кроме того, китайцы опасались ввода в регион русских войск, что уже случалось либо под предлогом «охраны безопасности русских подданных», либо с карательными целями в связи с повстанчеством. Стоит заметить, что Алтайский округ привлекал пристальное внимание российской стороны, потому что округ составлял в географическом и этнографическом отношении естественное продолжение Семипалатинской области, открывал России доступ к торговоэкономическому влиянию на Западную Монголию и Синьцзян.

Вопрос о выселении русских из пределов Алтайского округа возникал неоднократно. Уже первый руководитель округа Си Хэн приступил к последовательному вытеснению русских торговцев и промышленников. Так, он отдал указание выселять безбилетных русских купцов из кочевий казахов и тувинцев и ввел запрет для жителей Шарасумэ не только продавать, но даже сдавать внаем русским жилые помещения. Новый руководитель региона князь Палта ${ }^{13}$ занимал по «русскому вопросу» двоякую позицию. С одной стороны, в период его руководства позиции России в регионе укрепились, а губернатор Синьцзяна даже обвинял его в прорусской ориентации и продаже русским земельные участки на территории округа, что, возможно, и стало причиной его скорой отставки. С другой стороны, есть противоречивые данные о том, что в 1913 г. он настаивал на возвращении русских переселенцев в пределы Сибири. Его преемник Лю Чанбин был более дипломатичен и открыто этот вопрос не ставил, но также стремился изгнать русских из округа. Сменивший его в 1915 г. Чень Кэ не трогал русских поселенцев, однако активно занимался вопросами китайской колонизации округа ${ }^{14}$. С началом Первой мировой войны и последующим падением престижа Российской империи отношение к русским подданным и, непосредственно, колонистам, ухудшилось. А с весны 1917 г. консулы неоднократно направляли в российское министерство иностранных дел сведения о падении престижа России, притес-

\footnotetext{
${ }^{8}$ Қанас (каз. яз). Последняя кержацкая семья эмигрировала в Австралию в конце 1990-х гг. Сейчас на месте поселка Хом живут тувинцы и здесь находится этноаул.

${ }^{9}$ Цутому Цукадо. Участие в войнах русских старообрядцев в округе Алтай (Синьцзян-Уйгурский автономный район КНР) // Международные Заволокинские чтения. Рига, 2016. Сб. 4. С. 521.

${ }^{10}$ Моисеев В.А. Россия и Китай в Центральной Азии (вторая половина ХІХ в. - 1917 г.). Барнаул, 2003. С. $294-295$.

${ }^{11}$ Там же. См. также: Воскресенский А.Д. Дипломатическая история русско-китайского Санкт-Петербургского договора 1881 г. М., 1995.

${ }^{12}$ Галиев В.В. Российские консульства в Синьцзяне (конец XIX - начало XX вв.), Алма-Аты, 2011. С. 38.

${ }^{13}$ Палта Ванг (1882-1920), правитель Алтайского округа в 1912-1914 гг.

${ }^{14}$ Моисеев В.А. Россия и Китай... С. 295.
} 
нениях со стороны китайской администрации и о случаях оскорблений русских подданных со стороны местных жителей ${ }^{15}$.

События Февральской революции практически не затронули русскую колонию в Китайском Алтае, хотя приход к власти в России Временного правительства обсуждался в Шарасумэ. Российский консул В.Ф. Люба ${ }^{16}$ пытался разъяснить значение произошедших в России событий местному русскому торговому обществу и гарнизонному конвойному отряду. На собрании офицеров конвойного отряда было принято решение «при полном подчинении велениям Временного правительства» и поддерживая среди частей строгую дисциплину, способствовать единению между частями, «принимающими известия с необычайным энтузиазмом» ${ }^{17}$. Местное торговое сообщество собрало 300 руб. и передало их в распоряжение Председателя Государственной Думы на нужды Красного Креста.

В русских поселках ситуация была сложной и неоднозначной. Одними из наиболее серьезных вопросов в Алтайском округе являлись неопределенность юридического положения колонистов и их прав на арендуемые земли, а также отсутствие в местах поселений российских органов исполнительной власти и правосудия. Консульство видело свою текущую задачу в «укреплении среди населения русских поселков начал Государственного строя» и «сохранении спокойствия», что было возможно только при условии «закрепления дружественных отношений с китайским населением» и местными казахами, среди которых имелись «превратные толки о происходящих в России событиях» ${ }^{18}$. В феврале 1917 г. русский гарнизон, расквартированный в крепости Шарасумэ был усилен дополнительным взводом из состава 11 Сибирской Стрелковой Артиллерийской Бригады. Консульство находилось в зоне контроля Омского Артиллерийского управления. Однако не исключалась ситуация, что в ближайшее время русские войска могут быть выведены из Шарасумэ.

В этих сложных условиях российскому консулу удалось сделать очень многое. В связи с массовым потоком казахских и киргизских беженцев из России в регионе существенно осложнилась продовольственная ситуация. Накануне посевной через Зайсанский продовольственный комитет консульство смогло добиться выделения для русских поселенцев продовольствия на сумму 5561 руб. и взять в ссуду на обсеменение полей в сумме 2398 руб. Предполагалось, что взявшие ссуду должны будут вернуть ее натурой после сбора урожая, доставив зерно в г. Бурчум и г. Шарасумэ для нужд российских войсковых частей в Алтайском округе ${ }^{19}$. Помимо этого, было получено согласие Правителя Округа на предоставление крестьянам тех же участков и угодий, которые они занимали в прошлые годы, с обязательством без разрешения консульства и Правителя не занимать новых земельных площадей. Об этом китайские власти оповестили местное население, а русское консульство - колонистов. Во избежание недоразумений крестьянам было предложено все дела разбирать при содействии образованных в поселках исполнительных комитетов и выборных от туземного населения, а также агентов консульства и китайских властей. С российской стороны последовало даже предложение разрешить участвовать казахам в русских исполнительных комитетах ${ }^{20}$, но Правитель округа отклонил это предложение ${ }^{21}$. Консульство и местные власти пытались поддерживать между русскими крестьянами и китайскими казахами мир и спокойствие, внушая тем и другим необходимость совместной жизни «на началах справедливости и уважения взаимных интересов» ${ }^{22}$.

\footnotetext{
${ }_{15}^{15}$ АВП РИ. Ф. 143. Оп. 491. Д. 3357. Л. 75.

${ }^{16}$ Люба Владимир Федорович (1861 - 14 июля 1928, Харбин) - российский дипломат, востоковед. В $1911-$ 1913 гг. - генеральный консул миссии в Урге, в 1913-1916 гг. - генеральный консул в Кобдо, в 1917-1920 гг. управляющий российским консульством в Кульдже.

${ }^{17}$ АВП РИ. Ф. 143. Оп. 491. Д. 640. Л. 314.

18 Там же. Л. 339, 357.

19 Там же. Л. 357.

${ }^{20}$ Исполнительные комитеты Временного правительства - коллегиальные органы исполнительной власти на местах, появившиеся в марте 1917 г. в России после упразднения должности губернаторов.

${ }^{21}$ АВП РИ. Ф. 143. Оп. 491. Д. 640. Л. 357.

${ }^{22}$ Там же. Л. 339.
} 
Для ознакомления русских колонистов с новым строем в России, приведения населения к присяге на верность Временному Правительству, создания на местах коллегиальных органов власти в форме исполкомов и третейских судов, оказания крестьянам продовольственной помощи в русские поселки Китайского Алтая и был командирован прапорщик Мошкин. За два месяца он посетил девять русских поселков ${ }^{23}$ (Заречный Чонкур, Чонкур ${ }^{24}$, Калгутон ${ }^{25}$, Теректы $^{26}$, Чубур-Чилик ${ }^{27}$, Кульдуден-Булак, Ушаши ${ }^{28}$, Нижняя Дала-Каба и Верхняя ДалаКаба) $)^{29}$, расположенных в районе озера Канас и притока Черного Иртыша р. Каба. Поездка была обусловлена необходимостью привести к присяге Временному правительству проживающих там русских колонистов, одновременно оценив численность и конфессиональный состав русских колонистов, их материальное положение и межнациональную ситуацию в регионе.

Русский анклав в Китайском Алтае просуществовал вплоть до середины 1960-х гг. Проживавшие здесь русские пытались сохранить традиционный и обособленный уклад жизни вопреки как внешнеполитическим, так и внутриполитическим событиям. Среди местных казахов, не владеющих русским языком, эти места известны до сих пор как место проживания «кержаков».

\section{Отчет \\ О поездке по русским поселкам Китайского Алтая Прапорщика Артиллерии Мошкина, временно прикомандированного к Российскому Консульству в Шарасумэ}

21 апреля 1917 года вследствие предписания г. Российского Консула в Шарасумэ, мною была совершена поездка с целью раздачи продовольственного пособия, ссуды на обсеменение полей, привода к присяге на верность Временному Правительству, разрешения споров между крестьянами и киргизами и собрания сведений для судебно-административной реформы поселков.

Поездка была совершена по следующему маршруту:

Заречный Чонкур. 22 апреля я прибыл в один из бедных русских поселков - Заречный Чонкур, состоящий из 11 православных русских семей и 3 семей чувашей, обитающих в неприглядных, в один сруб избах, разбросанных приблизительно на четырех десятинах. Печать бедности лежит на всем, начиная от внешнего вида поселян и кончая их постройками. В этом сказались: сравнительно недавнее прибытие (с 1915 года), склонность к китайскому ханьшину ${ }^{30}$ и малая урожайность хлебов в прошлом году вследствие градобития.

Ссуда на обсеменение полей здесь оказалась особенно кстати, и от нее отказались лишь две самые зажиточные семьи Мороткановых.

Жалоб на киргиз не было, кроме заявления поселянина Степанова, у которого этой весной пропали две лошади.

Запашка и посев производятся беспрепятственно.

\footnotetext{
${ }^{23}$ В названии всех поселений лежат казахские топонимы.

${ }^{24}$ Чонкур, Шұңқыр - яма (каз. яз.). Находится в районе Буыршын Алтайского округа СУАР КНР.

${ }^{25}$ Қалу тон (каз. яз.). Находится в районе Коктогай/Кёктогай, (Көктоғай (каз. яз.) Алтайского округа СУАР KHP.

${ }^{26}$ Теректы - тополиная, тополевое урочище (каз. яз.).

${ }^{27}$ Шубар-Шілік (каз. яз.).

${ }^{28}$ Правильно Уш-аши (Үш-аші (каз. яз.)).

${ }^{29}$ Қаба (каз. яз.) - приток Черного Иртыша, и по названию реки назван современный район.

${ }^{30}$ Ханьшин - традиционный китайский крепкий алкогольный напиток, дистиллируемый из пшеницы, риса, кукурузы, гаоляна, чумизы, сорго и номи. Вкус ханшина зависит не только от самого продукта, но и от способа его очистки. Имеет цвет от мутного до прозрачного и специфический запах. Крепкость напитка от 40 до 70 \% об. Названия ханшина ханшин, ханжа, хана или ханка получили известность в русской среде в середине XIX в. В самом Китае этот напиток также называют байцзю или шаоцзю - букв. «горячее вино», что намекает одновременно и на процесс выгонки, и на былой обычай употреблять напиток подогретым. Продажи этого напитка превышают по объему продажи виски, водки и рома вместе взятых.
} 
Молча, почти индифферентно заречные Чонкурцы приняли присягу на верность Временному Правительству. Почти также равнодушно отнеслись они и к вестям об уходе Отряда из Шарасумэ ${ }^{31}$. Какая-то слепая покорность судьбе слышалась в их вопросе: «как же мы будем жить дальше». Совет жить в дружбе и согласии с киргизами и всякие споры разрешать третейскими судами или обращаться к китайским и русским властям не без труда был усвоен крестьянами, привыкшими смотреть на киргиз как на рабское и бесправное существо, с которым можно лишь расправляться, но не судиться.

Чонкур. Это поселок, отделенный от Заречного Чонкура несколькими рукавами полноводного и бурного Бурчума, я посетил 23 апреля. 30 старообрядческих семей и 2 православные живут зажиточно. Избы в большинстве случаев в два сруба с прочными надворными постройками, с рубленными амбарами расположены в уличном порядке. Благодаря прибывшим в отпуск воинским чинам, поселяне проявляют интерес к перевороту и к своему новому положению, в связи с уходом Отряда из Шарасумэ.

Бесплатно получается газета «Земля и Воля» (партии ср.) ${ }^{32}$, которая, по словам наиболее грамотного и развитого поселянина писаря Григория Боброва, мало их удовлетворяет, так как «про войну пишут мало, а про ерунду сколько угодно». При первых известиях о комитетах ${ }^{33}$, таковой был избран в количестве 6 человек и заменил собой упраздненного старосту, который фактически, особенно в глазах женского населения, продолжал оставаться носителем власти. При отсутствии инструкций и каких бы то ни было указаний, комитет на свое формирование и выработку компетенции потратил около трех недель ценного рабочего времени, не успев за это время наладить даже правильное пользование арычной водой, благодаря чему задержалась распашка полей. Раньше распределением воды для поливов заведывал староста Макар Трескин и никаких недоразумений на этой почве не было.

Чонкурцы, за исключением 7 семей, отказавшихся от ссуды, испытывают, благодаря прошлогоднему градобитию, нужду в семенах, а некоторые и в насущном хлебе. Это вопрос долго был предметом обсуждения комитета, который, однако, при отсутствии своей авторитетности и взаимному недоверию поселян, никакой пока пользы не принес. Были попытки со стороны комитета привести в наличность имеющиеся хлебные запасы поселян и даже намерение реквизировать излишек зерна, но такие попытки встретили протесты, что было вполне естественно, так как имеющегося у некоторых запаса зерна едва ли хватит на посев и пропитание до нового урожая. Яркой характеристикой взаимного отношения чонкурцев служит факт реквизиции около 70 пудов зерна у отсутствовавшего крестьянина Брекотнина. При испрошении у консульства разрешения на реквизицию, комитет сослался на имеющиеся у него сведения, что Брекотнин, проживающий сейчас в Бурлаке (русские пределы), сеять в этом году не приедет, и его зерно будет без пользы лежать в сусеках. В действительности дело обстояло иначе, и консульство было введено в заблуждение. Спустя два дня после распределения зерна между нуждающимися и не имеющими нужды в хлебе (Зайцева, которая даже продавала свой хлеб), приехал Брекотнин с работниками сыновьями и из его слов, не опровергнутых чонкурцами, выяснилось, что он своевременно известил общество о своем намерении в этом году сеять и поселиться в Чонкуре, для чего у него был готов лес на избу. Иов же Бобров, наиболее авторитетное лицо в поселке, которому было вверено на хранение зерно Брекотниным, из опасения самому подвергнуться реквизиции, вместо должной охраны чужого имущества, сам обратил внимание комитета на зерно при одобрительном участии остальных. В результате Брекотнин остался без семян и насущ-

\footnotetext{
${ }^{31}$ Имеется в виду уход по требованию китайских властей русского конвойного отряда из Шарасумэ в 1917 г.

32 «Земля и воля» - еженедельная газета верхнеуральской организации партии социалистов-революционеров. Издавалась в Верхнеуральске с 28 мая по 3 сент. 1917 (всего 13 номеров); выходила под лозунгом «В борьбе обретешь ты право свое». На страницах «3. и в.» освещались хроника рев. событий, новости социально-полит., культ. жизни города и Верхнеурал. уезда, материалы, содержавшие критику в адрес правительства, и др. Газета печаталась в типографии М.И. Неизвестнова, ред. был M.M. Соколов. URL: http://chel-portal.ru/enc/ zemlya i volya (дата обращения: 19.05.2020).

${ }^{33}$ Исполнительные комитеты Временного правительства - коллегиальные органы исполнительной власти на местах, появившиеся в марте 1917 г. в России после упразднения должности губернаторов.
} 
ного хлеба принужден возвратиться в Булак, если ему не удастся получить обратно хоть часть реквизированного зерна.

Отношение чонкурцев к киргизам можно подразделить на две категории: 1) общественного характера, создающееся на почве земельных интересов и 2) личного характера, возникающее из-за эксплуатации киргиз как поденщиков и как постоянных работников. Обе эти категории отношений оставляют желать лучшего, так как покоятся на взгляде на киргиз, как на рабское покорное существо, в особенности это сказывается при пользовании киргизами как поденщиками. В основе этого пользования лежит не соглашение, обусловленное известной заработанной платой, а возмутительная эксплуатация полуголодного раба, получающего за свой труд не вознаграждение, а подачки. Например, киргизы молотят хлеб, помогают засаживать и полоть, толкут в ступах просо, плетут из камыша ковры - и за все это получают обрезки хлеба, остатки снятого молока, ни на что не нужное тряпье, да и это подаяние они имеют после долгих просьб и ожиданий. Таким же образом чонкурцы оплачивают и тяжелый труд перевозчика через Бурчум, которым для русских установлена минимальная плата 10 коп. с лошади, тогда как с киргиз они берут и до 50 коп. Не в лучших условиях протекает труд киргиза - постоянного работника, который за рабочий сезон получает 5 пудов семян, право пользования плугом и жалкие остатки обеда. Отношения на почве столкновения земельных интересов возникли лишь в этом году с приездом в Чонкурскую долину киргизского цзаляна ${ }^{34}$ Бурчакпая, который, несмотря на протесты крестьян, запахивает правый берег Калгутонки, служивший для чонкурцев в прошлые года местом для сенокоса. На мое предложение Бурчакпаю прекратить запашку лугов, ввиду распоряжении Правителя края ${ }^{35}$ о сохранении за чонкурцами всех прошлогодних угодий, киргизский цзалын ответил, что у него есть разрешение от того же Правителя на пользование правым берегом Калгутонки. Китайский Галдай ${ }^{36}$, к которому я ездил за выяснением этого недоразумения, накануне уехал далеко в горы и видеть его мне не пришлось. Чонкурцы подали в Консульство ходатайство об ограждении их интересов, так как никакого органа для разрешения не только общественных споров, но и личных столкновений между поселянами не имеется, а понятие третейского суда им неизвестно. Единственным лицом, разрешающим споры на месте, является казак Давыденко.

Калгутон. Этот поселок из 40 семей старообрядцев-общинников и православных широко раскинулся по левому берегу реки Калгутонки на обширной долине, которая могла бы свободно принять на свои плодородные угодья несколько десятков, а то и сотен новых семей. Его я посетил 27 апреля.

Несмотря на религиозные различия, поселяне живут дружно, что сказывается в отсутствии жалоб и в быстром, не вызвавшем никаких недоразумений вопросе о семенах. Имеющие излишек таковых добровольно уступили неимущим и в количестве 7 человек отказались от ссуды в пользу бедняков. В поселке имеется комитет из 4 лиц, который теперь занят вопросом как достать хлеб для пропитания до нового урожая. Так же как и оба Чонкура, калгутонцы намереваются достать рожь и пшеницу в русских пределах через Зайсанский Продовольственный Комитет при поддержке Российского Консульства в Шарасумэ, с каковою целью ими будут командированы в Зайсан члены комитета с приговором общества.

Несмотря на самый разгар пашни, поселяне и поселянки в праздничных одеждах явились все присягать Временному Правительству и радостно приветствовали происшедший в России переворот ${ }^{37}$. Предстоящий уход отряда из Шарасумэ не вызвал большого огорчения калгутонцев, которые при хороших взаимных отношениях между собою поддерживают

\footnotetext{
${ }^{34}$ Киргизский цзалян (цзалын) - староста.

${ }^{35}$ Правитель края - имеется в виду правитель округа, окружной начальник - даотай.

${ }^{36}$ Китайский галдай - китайский чиновник, должностное лицо - см.: Селицкий И.В. Кульджинские переселенцы пограничной с Китаем полосы: экон.-этногр. очерки и быт. жизнь джаркент. таранчей и дунган. Казань, 1905; по другим данным, - китайский пограничный чиновник - см.: Тюркологические исследования. 2018, Т. 1. № 2. С. 145.

${ }^{37}$ Имеется в виду Февральская революция 1917 г.
} 
такие же хорошие отношения с киргизами. Последние вблизи Калгутона ни зимовок, ни пашен не имеют, а приходят в их долину в середине мая. Плохо охраняемый киргизский скот производит потраву лугов ${ }^{38}$, что продолжается незначительное время. Административным органом является староста, авторитет которого нисколько не упал с образованием комитета, на который сами члены смотрят как на сельскую думу. Орган судебной власти здесь отсутствует, даже не имеется казака, и калгутонцы высказывают пожелание иметь у себя совместно с Чонкурцами волостной суд.

Теректы. В этот исключительно старообрядческий поселок я прибыл 30 апреля. В узкой плодородной долине разбросаны 11 новеньких изб и наскоро возведенных надворных построек - все это возникло с 1915 года и дальнейшему развитию здесь колонизации помешала война. Единственным неудобством в географическом отношении является близость киргизской кочевой дороги, и во время кочевок крестьяне страдают от потравы лугов и пашен, но значительного вреда эти потравы крестьянам не причиняют, так как киргизы вблизи поселков не останавливаются, а о зимовках и киргизских пашнях здесь нет и помину. В общем отношения крестьян с киргизами удовлетворительные и были бы совеем хорошие, если бы не имели место единичные пропажи лошадей с пашен, что объясняется отсутствием пастуха и должной охраны скота своими крестьянами. Такое печальное явление совпало с моим приездом в Теректы. У крестьянки Булыгиной пропали с пашни две лошади, на розыск которых отправились староста с двумя понятыми, возвращения их я не дождался. Общность религиозных убеждений, обилие плодородной земли и то обстоятельство, что теректинцы осели здесь по обоюдному согласию, создали условия для мирной и дружной жизни. Чувствовалось, что горе Булыгиной было общим несчастьем, и можно быть уверенным, что ея пашни не останутся необработанными.

Жалоб на отсутствие семян и хлеба не было, и 6 человек, получившие ссуду, взяли ее не из нужды, а из соображения: раз вписана ссуда на них, то отказываться не надо, тем более, что при общем благосостоянии у ссудодержателей нет страха за доставку зерна.

Площадь посева в этом году предполагается не менее прошлогодней. Отсутствие наиболее развитых теректинцев, уехавших в поисках лошадей Булыгиной - с одной стороны и разгар пашни с другой - мешали выяснить действительное отношение крестьян к перевороту и предстоящему уходу Отряда из Шарасумэ. Даже близость русской границы (8 верст), откуда они несомненно могли получать известия об исторических событиях внутри России, не изменили их уклада жизни, комитета у них нет и всеми делами ведает староста, который разрешает и споры крестьян.

Чубар-Чилик. 1 мая я приехал в Чубар-Чилик, расположенный в 4 верстах от Теректов, на правом берегу живописной Кабы, в небольшой узенькой долине, совершенно уединенно, поселились 13 старообрядческих семей одного толка. Четырехлетняя оседлая жизнь, непрерывный труд и обилие леса дали возможность завести хорошие избы с солидными надворными постройками и соответствующим инвентарем и, например, обиталище Шимолина скорее напоминает помещичью хуторскую усадьбу, нежели двор крестьянина-колониста. Заботы крестьян распространились и за пределы поселка: ими положена прекрасная дорога к пашне, по крутому откосу горы, где не так давно едва проезжали верхом, а теперь свободный путь на телеге. Своей дружной жизнью, взаимными любовью и уважением, этот поселок резко выделяется из всех других, в этом отношении рядом с ним могут быть поставлены лишь Теректы.

Ссуду на семена никто не взял, отказались даже те, на кого была написана: у крестьян своего хлеба хватило на семена, достанет и до нового урожая.

Со всеми киргизскими старшинствами, по словам поселян, они живут хорошо, кроме старшинства Джакова - Кибил, со стороны которого нужно опасаться потравы, в предупреждение чего поселяне просили командировать к ним с 1 июня до конца уборки хлеба одного или двух казаков. Свое временное право на запахиваемую землю Чубар-Чиликцы, как и теректинцы, основывают на письменном и словесном разрешениях киргизских старшин,

\footnotetext{
${ }^{38}$ Потрава - порча скотом или птицей чужих угодий.
} 
поэтому нет никакого основания опасаться за недоразумения на этой почве. Пропажа лошадей - явление для Чубур-Челикцев незнакомое, но тем не менее в поселке имеется свой пастух.

Такая обособленная и полная своих интересов жизнь сказалась в почти равнодушном отношении к русским внутренним событиям, которые заинтересовали поселян постольку, поскольку это может отразиться на войне, где сражаются их братья, мужья и сыновья.

Во главе управления стоит староста, а про комитет крестьяне говорят: «он нам не нужен, а если прикажете - выберем». Предстоящий уход Отряда из Шарасумэ рассматривается Чубар-Чиликцами, как крушение их надежд быть собственниками насиженного места.

Право владения землей, в силу дружных отношений между собой и киргизами, дает основание думать, как предполагают и сами Чубур-Чиликцы, удержится за ними на долгие годы.

Чубар-Чилик я покинул 3 мая.

Кульдюден-Булак. В 30 верстах от Чубур-Чилика, на единственной в этом месте киргизской кочевой дороге с плодородной почвой неуютно безалаберно расположились в четырех наскоро построенных избах 7 семей: 3 семьи старообрядцев Артемий Семенников с женой и детьми, Дементий Ошлаков с женой и сыном и 4 семьи православных: Кирилл Черепанов с детьми и снохой, Григорий Кобылин с женой, Василий Бочкарев с женой и 2 дочерьми и Петр Казанцев с женой и дочерью - все они, за исключением последнего, приехали сюда в марте этого года и поселились вопреки желанию Казанцева, приехавшего прошлогодней весной и без предварительного соглашения с киргизами, имеющими здесь пашню и постоянные кочевки. Поселяне не оповестили даже консульство о своем переселении сюда, поэтому для меня видеть их здесь, числящихся в Дала-Кабе, было большой неожиданностью. С первых же слов посыпались жалобы на Петра Казанцева, обвинения его в притеснении их на киргиз, которые при кочевке вытаптывают их пашни, а через некоторое время явились с жалобами и киргизы: Искак Каирбеков и Искак Амамбаев, последний от себя и 7 товарищей. Киргизы жаловались на Казанцева, который, запахал у Каирбекова 2 десятины залога (распашки), а у Амамбаева с товарищами 4 десятины. Попытки киргиз, по их словам, отстоять свое право на землю, вызвали со стороны Казанцева угрозы расправиться оружием. В довершение всего от киргизского цзанги ${ }^{39}$ Джелмакая поступила жалоба на поселян, запахавших всю кочевую дорогу. Джелмакай заявил, что при кочевке они неминуемо должны потоптать крестьянские пашни. Во избежание недоразумения в будущем Джелмакай просил выселить отсюда самовольно явившихся колонистов.

Жалобщикам Амамбаеву и Каирбекову я приказал явиться для разрешения их дела в Ушаши вместе с Казанцевым, которого в то время не было в поселке. После привода к присяге и раздачи ссуды и пособия, я в тот же день поехал в Ушаши, куда прибыл вечером.

Ушаши. В первый же час приезда в Ушаши, от Алексея Петровича Петрова поступила жалоба на 7 семей поселка, самовольно приехавших в прошлом году в Ушаши и поселившихся здесь вопреки желанию общества, не войдя в предварительное соглашение с киргизами. Правда, общество до прошлого года было невелико - всего 8 человек, но оно жило дружно, так как пришло по взаимному согласию своих членов и свое право оседлости основывало на письменном договоре с киргизами. Теперь же на этой арендованной земле поселились нежеланные новоселы: две семьи Воронковых, Краснопеев, Минеев, Буньков, Самойлов и Шарыпов, которые считают себя такими же хозяевами, на арендованной ими долине, кроме, впрочем, Шарыпова, который самовольно занял лишь усадебное место, а пашню отдельно от себя арендует у киргиз. Петров от имени своего и своих товарищей старожилов просил Консульство выселить новоселов и тем создать спокойную и мирную обстановку в поселке для труда и жизни. Новоселы в свое оправдание говорят, что земля здесь китайская и права у них на нее такие же, как и у старожилов. Такое подразделение поселка на два враждующих лагеря, примирить которые не было никакой возможности, губительно отражается на общей жизни Ушашей. Постоянная брань и угрозы слышатся с обеих сторон. Дракой кончаются споры, кому в данный день пользоваться арыками.

\footnotetext{
${ }^{39}$ Киргизский цзанги - старшина, подчиняется угурдаю (см. ниже).
} 
Например, старожил Буньков настойчиво просит сломать мельницу новосела Воронкова, стоящую на арыке, которым орошается его, Бунькова, паек. Между тем из расспросов обеих сторон выяснилось, что мельница работает два дня в неделю, обслуживая новоселов, а Буньков пользуется арыками 1-2 дня в течение двух недель. Оба как будто бы успокоились, когда я распределением очереди пользования арыками легко примирил их интересы, у Петрова на мельнице случилась кража зерна, виновника называют во вражеском лагере, улик положительно нет никаких, и сам Петров теперь не решается официально поддерживать свое первоначальное обвинение против сына старосты Бунькова. Старожилы все же принуждены считаться с новоселами, и староста избран от последних, а в комитет вошли из обоих лагерей по одному. Но совместная общественная работа не вносит успокоения в жизнь ушинцев. Жалоб на притеснения со стороны киргиз не было. Кочевники близко не подходят, зимовок и пашен не имеют. Случившаяся в этом году кража лошадей у Русаковой - явление не единичное. О всех таких делах поданы соответствующие заявления в Консульство, но должного решения они до сих пор не получили, так как дознания по этим делам производились иногда самими потерпевшими без участия казака, который все равно не угодил бы. Потерпевший видит вора лошади во всяком киргизе, с которого силой можно взыскать вместо одной 2-3 лошадей. Казаки в таком «правосудии» потерпевшему отказывают, а потому, видимо, последними игнорируются. Ушашинцы-старожилы, имея прочные избы, надворные постройки и благоустроенные огороды, успели полюбить свою долину, и уход Отряда из Шарасумэ поселил в них тревогу за свое прочное существование. Вся надежда у них на то, чтобы заключить долгосрочный арендный договор. Для новоселов же этот вопрос безразличен, так как многие из них подумывают вернуться в русские пределы. Отношение тех и других к перевороту - безразличное.

K моему отъезду из Ушашей поселяне пашню еще не закончили, но предполагают заселять несколько больше прошлогоднего, благодаря прибывшим в отпуск солдатам.

В хлебе и зерне ушашинцы нужды не испытывают, однако от ссуды, кроме троих, никто из остальных не отказался. Из долей отказавшихся, общество не пожелало составить приговор, коим уделит нуждающемуся Воронкову, несмотря на усиленную его об этом просьбу.

5 мая в Ушаши приехали киргизы из Кульденен-Булака Каирбеков и Амамбаев с двумя товарищами, прибыл и Казанцев. Из опросов сторон нельзя было установить количество спорной земли и какими семенами она засеяна. Для этого мною был командирован на место казак Фролов, который при участии сторон и понятых осмотрел спорные участки и представил цифры, совпадающие с данными в жалобе киргиз. Казанцев, не опровергая факта запашки киргизских залогов, отрицал в этом самоуправство, говоря, что залог Каирбекова он запахал с разрешения последнего, а пять полос Амамбаева и товарищей достались ему при переделе земли, в котором принимали участие двое компаньонов Амамбаева. Противные стороны отрицали утверждение Казанцева; свидетелей ни у одной из сторон не было. Казанцев предложил киргизам, по их процессуальному обычаю, принять присягу у муллы в подтверждение своей правоты, и тогда пусть дело решится в их пользу. Киргизы согласились. Ввиду отдаленности муллы и сложности обряда, окончательное разрешение дела было перенесено на 10 мая. В этот день явились Казанцев и Амамбаев с товарищами. Каирбеков же примирился с Казанцевым и на суд не явился. Приехало много киргиз во главе с муллой и двумя цзалынами - Джомартом и Оспаном Кошкончиновым.

Мною было разъяснено сторонам значение третейского суда, и я предложил им избрать судей. Двое цзалынов со стороны киргиз и двое поселян Ушашинцев со стороны Казанцева постановили приговор, коим самовольно захваченные Казанцевым киргизские залоги возвратились Искаку Амамбаеву и его товарищам, которые повинны уплатить Казанцеву стоимость половины засеянных семян. Приговор, изложенный на русском языке, был вручен цзалыну Кошкончинову и на киргизском языке Ушашинскому Комитету. Казанцев остался недоволен решением и получил копию приговора. Съехавшиеся киргизы и присутствовавшие русские обещали и впредь спорные дела решать третейским судом. 
В Ушашах ко мне поступила жалоба солдатки Сарапуловой и гражданина Краснопеева.

О том, что их залоги, лежащие у самой русской границы, самовольно запаханы в этом году крестьянином Пограничной волости, деревни Александровки (русские пределы) Ларионовым, который прогнал их с оружием в руках. Ушашинец Шарыпов заявил, что его залог запахан крестьянином той же Александровки - Бородулиным.

6 мая я с Ушашинским Комитетом выехал в деревню Александровку. Здесь собравшимся Александровцам была изложена цель нашего приезда и разъяснена незакономерность (так в документе, но правильнее, вероятно, - незаконность. - E. Н.) переезда русско-китайской границы без разрешения властей и преступность самовольной запашки залогов русских колонистов в Китае. Оказалось, что этот вопрос обсуждался в Успенском Волостном Комитете, где были высказаны недопустимость переезда границы и резкое осуждение поступков Ларионова и Бородулина. Дело Шарыпова и Бородулина окончилось примирением, а спор Сарапуловой и Краснопеева с Ларионовым стал предметом разбирательства обоих Комитетов, которые единогласно постановили: залоги, запаханные самовольно Ларионовым, возвратить вместе с посевом Сарапуловой и Краснопееву, которые взамен этого должны уплатить Ларионову стоимость семян. В виду угроз сына Ларионова самовольно сжать спорный хлеб, Комитеты обязали деньги для Ларионова внести в Александровский Комитет для выдачи последнему по сбору урожая.

Вот оно отрадное явление в Ушашах. В 2 верстах от поселка, у ручейка Аю-Бая удобно расположился благоустроенный хутор Ивана Афанасьевича Мокина, из казаков. Наряду со скотоводством и хлебопашеством, Мокин занимается обжиганием извести, каковой промысел в этот первый год дал ему 1000 рублей барыша. Мокин является настоящим русским культур-трагером ${ }^{40}$ в этом мало отрадном уголке русских поселков. Если ушашинцы разбивают посуду, из которой пил поганый киргиз и обмывают дверные скобы, за которую бралась киргизская рука, то Мокин таких киргиз принимает у себя за чашкой чая, а когда приезжают с ночевкой к нему киргизы гости, то он считает своим долгом заколоть барана. Прекрасное владение киргизским языком, знание туземных обычаев и нравов, уважение к киргизам высоко поставили авторитет Мокина в глазах кочевников. Последние идут к нему не только за разрешением своих тяжб с русскими, но и за разбором между собою. Следующие два факта ярко характеризуют отношения Мокина к киргизам: Мокин имеет у себя работников киргиз и платит наряду с жалованием выкуп (калым) за их невест. Однажды Мокину один кочующий аул, не зная его, отказал в ночевке, об этом узнал Укурдай. На другой день негостеприимный аул на коленях вымаливал прощение у Мокина, и привел в подарок лучшего из табуна коня. Мокин обидчиков простил, а от коня отказался. Если киргизы уступчивы и миролюбивы к презирающим их ушашинцам, то в этом, несомненно, заслуга Мокина.

Нижняя Дала-Каба. Сюда я приехал на другой день. Всего в 15 минутах езды от Заречной Дала-Кабы, отдаленной пятью рукавами реки того же названия, расположился этот наполовину пустой поселок. Меня встретили колонисты, которые с первого же взгляда произвели неблагоприятное впечатление: испитые лица, злобное выражение в глазах и неряшливость в одеждах свидетельствовали о многом.

Недовольство и жалобы слышались на всех: и на граждан соседних поселков, и на казаков, и друг на друга, и на киргиз. К последним они строят свое отношение на плотно вкоренившемся взгляде: киргиза в избу пускать нельзя, в нем можно видеть только раба, основывать свои права на силе. Так, не стесняясь, высказываются сами дала-кабинцы и открыто порицают заречного Ивана Беляева, который видит в киргизе равного себе соседаземлевладельца.

При сравнительно частых пропажах лошадей, кабинцы не имеют пастуха. В этом году они совместно с заречными крестьянами наняли было пастуха киргиза с платой по 80 коп. с лошади, а когда киргиз пришел получать обусловленные 50 коп. впредь, они стали давать только 40 коп. и не соглашавшегося на это киргиза с бранью выгнали из поселка. Винов-

\footnotetext{
${ }^{40}$ Правильно: «Культуртрагер» (нем. Kulturträger).
} 
ником этого факта считают Беляева, который не хотел общего табуна и тут же подтверждают, что Беляев платит теперь 2 рубля с лошади.

Характерен и следующий факт: в марте с.г. у Буркова пропала со двора лошадь, разыскивать которую поехали 5 понятых со старостой. Все удостоверяют, что след за 50 сажень не довел до аула киргиза Баркая. Далее, одни утверждают, что след здесь прервался, а другие, как Шарыпов, показывают, что след затоптанный в 5 саженях от аула Баркая, вновь обозначился и пошел от последнего дальше, но следить его понятые не пошли. В результате такого дознания у потерпевшего и у 3-х понятых создалась уверенность, что виновник кражи лошадей - Баркай.

В основе своей оседлости нижни-далакабинцы имеют самоуправство, и это сказалось в их отношениях к киргизам: приходится пожалеть, что они не берут пример с Ивана Беляева и по-прежнему продолжают смотреть на туземцев как на покорных рабов. Между тем здесь много данных для мирного сожительства с киргизами: масса свободной и удобной земли, близость киргизского Галдая, готового всегда беспристрастно разрешать их споры, наличность казаков в Заречной Кабе и, наконец, авторитет Ивана Беляева, который, несмотря на завистливое и потому недоброжелательное отношение к нему, всегда готов быть посредником в недоразумениях с киргизами.

Естественно, поэтому кабинцы с грустью узнали, что наш отряд покидает Шарасумэ. Теперь они как бы предоставляются самим себе и должны резко изменить свое отношение к киргизам, чтобы гарантировать себе дальнейшее спокойное сожительство. Даже верхними дала-кабинцами поселяне недовольны, считая их подстрекателями киргиз в потраве их пашен и лугов.

В таких людях было бы странно искать отклика на то, что непосредственно не касается их повседневных личных интересов, а отсюда почти индифферентное отношение к перевороту и к историческим дням, переживаемым Россией. Мое пространное объяснение внутренних русских событий не вызвало никаких вопросов и возражений, раздалось только несколько голосов благодарности за привод к присяге новому правительству.

При склонности дала-кабинцев к китайскому ханьшину и слабой прошлогодней урожайности, от ссуды здесь никто не отказался, в том числе и приехавшие сюда крестьяне Зиновьев и Ануфриев, единственные представители поселка Усть-Каба, куда я лично заехать не мог за неимением времени. По словам этих поселян, живут они крайне недружелюбно и постоянно спорят из-за парома. Каждый хочет быть содержателем его. Для характеристики этих колонистов: Зиновьев, имея разрешение на паром, объявил монополию на Иртыш и силой препятствует китайцам переправляться на своих собственных лодках, принуждая, таким образом, пользоваться своим паромом за высокую плату. Об этом самоуправстве рассказал мне китайский Галдай. Мне немедленно пришлось послать Зиновьеву соответствующее предписание. Ануфриев, убеленный сединами старик, совершенно сознательно, ограждая сено от потравы голодного киргизского верблюда, воткнул в его бок палку с гвоздем, за что обязался уплатить тогда же, а остальные отказал, ссылаясь на то, что верблюд остался жив. Пришлось доказывать Ануфриеву, что платит он за поранение верблюда, а не за смерть. Только после этого и под давлением общества он при мне уплатил остаток киргизу, который отказался от предъявленного к Ануфриеву обвинения в краже с 20 верблюдов 2 пудов шерсти. На того Ануфриева заявил жалобу Ефимов, обвиняя его в умышленной порче рыболовной снасти - винтеля. Последнее дело было решено третейским судом, который жалобу Ефимова оставил без последствий.

Выборный здесь Комитет не пользуется популярностью среди поселян и бессилен устранить их постоянные недоразумения.

Перед тем, как заехать в Верхнюю Дала-Кабу, я с Нижне-Дала-Кабинским Комитетом и Иваном Степановичем Беляевым посетили китайского Галдая, который приветливо нас принял и предложил всем чаю. Галдаю я передал содержание дел о краже лошади у Бурковой и Полторанина; оказалось, что по этому вопросу послан запрос Правителю края. От Галдая я услышал жалобы на вышеупомянутое самоуправство на Иртыше усть-кабинца 
Ануфриева и на верхне-дала-кабинца Самойлова, вновь избившего нагайкой киргиза. На нашу просьбу оградить колонистов от киргизских потрав, Галдай обещал полное содействие, и в конце беседы условились все споры киргиз и русских разобрать при участии местных властей с обеих сторон.

Верхняя Дала-Каба. Сюда я приехал 14 мая. История заселения этого поселка также имеет в прошлом самоуправное занятие киргизских аулов, сопровождавшаяся и изгнанием их обитателей. Такие прискорбные факты легли в основание взаимоотношений крестьян с киргизами: и до сих пор печать насилия лежит на этих отношениях. Русские базируют свое право владения на силе и не могут отрешиться от взгляда на киргиз как на собак, с которыми они до сих пор в лице своего старшего Ванифантия Самойлова расправляются нагайкой и кулаком. Киргизы не могут забыть вытеснения их из зимовок и простить продолжающееся насилие над ними. При таком положении здесь часты кражи лошадей, потрава пашен и лугов, постоянные споры из-за арычной воды. А между тем в Верхней Дала-Кабе есть и благоприятные условия для мирного сожительства с киргизами.

С ранней весны зимующие здесь киргизы укочевывают, а остаются лишь киргизыземлепашцы, то есть народ оседлый и постоянный в своем составе, а потому хорошо известный местным колонистам. Да и самые требования этих киргиз не идут дальше того, чтобы поселиться в своих прежних зимовках, частью занятых поселянами, а частью свободных, но стоящих вблизи крестьянских изб и выгонов.

Второе благоприятное условие - близость китайского галдая, который даже к Самойлову относится терпимо и беспристрастно и всегда готов разобрать их тяжбы с киргизами.

К сожалению, граждане верхней Дала-Кабы игнорируют и свою, и китайскую власти, предпочитая собственную расправу нагайкой мирному и полюбовному решению спора.

В 6 верстах от них живут казаки, но они за дальностью их не приглашают, да и потому, что ныне казак, по их мнению, не истинный страж их интересов и препятствует их самоуправству и насилию, отказывая представлять к киргизам какие-либо требования без установления факта правонарушения. Например, казаки отказываются без выяснения виновности такого-то киргиза в краже лошади отобрать у него в виде эквивалента 2-3 лошади, по указанию потерпевшего крестьянина.

Такими соображениями вызвана жалоба дала-кабинцев на казака Фролова.

Кража лошадей здесь явление частое, но пастуха все же не имеется.

Дала-Кабинцы всецело поглощены интересами своей повседневной будничной жизни, и известия о перевороте встретили равнодушно, тогда как много было разговоров и расспросов относительно отозвания Отряда из Шарасумэ. Это обстоятельство вселяет в них тревогу и опасение за будущее.

Киргизы не забыли нанесенной им обиды и успокоятся лишь тогда, когда им возвратят их зимовки.

Этот поселок не имеет ни старосты, ни комитета, так как насчитывает всего 7 семей; присоединиться к нижнее-далакабинскому комитету он не желает. За старшего в поселке Ванифатий Самойлов - лицо энергичное и «язычник», по выражению поселянина.

Причины, вызвавшие здесь нужду в семенах те же, что и в Нижней Дала-Кабе: от ссуды отказались лишь самые зажиточные семьи Плотникова и Загорулько, а в замене их были удовлетворены Василиса Ушакова, Михаил Красков и Ванифатий Самойлов.

15 мая утром я покинул Верхнюю Дала-Кабу и вечером вернулся в Чонкур, откуда через день выехал в Шарасумэ.

Заключение и выводы. Великая война революционного движения, которая так судорожно и болезненно охватила могучую Россию и своей опьяняющей свежестью и стихийной силой захлебнула недавних обывателей и заслонила собой неотложные задачи момента победу над вековым врагом - немцем, лишь тихим ручейком докатилась до колонистов Алтайского округа в Китае.

Громадная отдаленность от очагов движения, весьма слабая сообщаемость с городскими центрами, полное отсутствие газет, почти поголовная безграмотность, бытовые и экономи- 
ческие особенности заграничной жизни не могли не ослабить до максимума впечатления от переживания Россией внутренних исторических событий. В особенности такой полный индифферентизм оказался в поселках, исключительно старообрядческих, живущих замкнуто и уединенно, как Чубар-Чилик и Теректы. Не проявили интереса к судьбам родины и такие, как Заречный Чонкур, Верхния и Нижния Кабы, всецело погрузившиеся в одну личную жизнь и повседневные споры.

В Верхней Дала-Кабе одна православная семья Плотникова отказалась даже принять присягу без присутствия священника, и мои доводы, что это присяга гражданская и не соединена с целованием Святых Креста и Евангелия, убедили лишь старика и его сноху, старуха же осталась непоколебима и из-за двери угрожала мужу страшным судом. Когда же я записывал его фамилию в список, то старушечий голос с отчаянным укором говорил: «смотри старик, что написано пером, то не вырубишь топором». Старик виновато опустил глаза и, видимо, раскаялся.

Гораздо с большим интересом отнеслись к перевороту те поселки, куда прибыли в отпуск солдаты, как Чонкур, да и тут вся созидательная работа свелась к избранию комитета и упразднению должности старосты, который по понятиям чонкурцев, хотя и является полезным, но как носитель старой власти должен быть устранен от деятельности.

Изменение государственного строя здесь служило даже темой для проповеди духовного настоятеля старообрядцев-общинников - Иова Боброва, который после обедни в молитвенном доме доказывал молящимся, что отрекшийся Николай Второй был антихрист, что через три года, которые надо проводить в посте и молитве, последует кончина мира.

Наиболее правильно функции комитета поняты калгутонцами. Здесь комитет действует на правах сельской думы при сохранении в целости власти старосты.

Вообще революция в России была встречена спокойно, так как китайские колонисты ${ }^{41}$ не чувствовали на себе гнета старой власти в связи с чрезмерными налогами и поборами так, как испытывали это крестьяне в России, на которых лежало много обязанностей при отсутствии прав. Здесь благосостояние и мирная жизнь зависит от самих крестьян, так как земли вдоволь, а повинностей нет никаких. Единственный тревожный вопрос - это киргизы, и от самих крестьян зависит наладить эти отношения.

Гораздо сильнее сказался на настроении и жизни поселян отказ Временного Правительства от аннексий и решения Министерства Иностранных Дел вывести Отряд из Шарасумэ.

Те поселяне, которые приехали в Китайский Алтай временно, без труда и горечи поехали бы в Россию, тем более им рисуется радужная перспектива иметь большие наделы на родной земле. Таковы Петр Казанцев в Кульдюнен-Булаке и его соседи, для которых уход Отряда почти безразличен. Также реагируют на этот вопрос, хотя и по другим мотивам, колонизаторы вроде Беляева на Кабе и Мокина в Ушашах, которые высоко поставили себя в глазах туземцев, сжились с ними и нисколько не боятся своей участи.

Другие же, а таких большинство, привыкли смотреть на киргиз как на бесправных рабов, иметь дело с которыми можно только при помощи кулака и нагайки, и естественно для таких уход Отряда - болезненный, волнующий вопрос. Они чувствуют, что для прочности своего существования они должны переродить свои отношения к киргизам и выработать в себе взгляд на них, основанный на уважении их прав и личности.

Больше других приуныли дала-кабинцы, которым приходится отказаться теперь от роли воинственных завоевателей края и стараться загладить свои грехи при первоначальном заселении, сопровождавшемся насилием над беззащитными туземцами. Лишь силой добрых отношений, полюбовным разрешением недоразумений и при наличии уважения туземцев, обеспечится им продолжительная здесь жизнь. Перед ними трудная задача отрешиться от права сильного и возвыситься в глазах киргиз до культурных граждан Великой Свободной России, для чего нужны, помимо слов, дела, которые заставили бы киргиз забыть прошлое и зажить общей жизнью с русскими колонистами.

\footnotetext{
${ }^{41}$ Имеются в виду русские колонисты в Китае.
} 
Взаимоотношения поселян между собою различны, они могут быть подразделены на три группы. Прекрасные отношения создались там, где поселились старообрядцы одного толка, по предварительному соглашению, каковы Чубар-Чилик и Теректы. Вполне удовлетворительно живут между собой те, где нет религиозной вражды, как Калгутон, в котором староверы не так яро охраняют свои традиции и живут с православными совместной жизнью, наконец, Чонкур и Ушаши, где взаимоотношения поселян оставляют желать лучшего.

В этих поселках наиболее рельефно сказались, с одной стороны, религиозная рознь православных и старообрядцев, с другой стороны, вражда старожилов к вновь прибывшим без их согласия колонистам. Отсюда распределение на два лагеря. Никакой ни материальной, ни нравственной поддержки они не окажут друг другу, и каждый брезгливо смотрит на другого. Например, в Чонкуре куплен сепаратор, которым пользуются все, имеющие в нем нужду старообрядцы, а православная семья Кузнецовых должна была завести отдельно свой, так как ей даже за плату не разрешали пропускать молоко.

Старообрядческие семьи переселились сюда из-за желания обособиться, оградить себя от религиозных влияний и создать благоприятную почву для ограждения дорогих им традиций и обычаев от влияния извне. Поэтому каждое новое незнакомое им лицо в поселке нежелательно и, даже не узнав его достоинств и недостатков, - уже видят в нем недруга. Эти пришлые люди, не считаясь с этими обстоятельствами, внедряются в их среду - в результате вечные ссоры и вражда, как например, в Ушашах. Эти ссоры, за отсутствием местных судей, остаются часто неразрешенными, также нет авторитетной власти, которой бы повиновались. Эти дела решаются Комитетом, где таковой имеется, или старостой, но приговоры редко приводятся в исполнение. Имеющиеся в некоторых поселках казаки раньше пользовались общим доверием, а теперь с ними как с носителями старой власти, мало считаются, тем более казаки отказываются исполнять их незаконные требования, а потому редко приглашаются. Так не был поставлен в известность казак Давыденко, когда реквизировался в Чонкуре и затем делился хлеб Брекотнина, так как чонкурцы знали, что Давыденко известно, что Брекотнин приедет сеять хлеб в Чонкур и естественно протестовал бы против этого решения.

Более всего волнует наших колонистов вопрос о хлебе. На семена им хватит, но многие семьи не имеют хлеба на пропитание, и все надежды возлагались на то, что достанут его в русских пределах через Зайсанский Продовольственный Комитет при содействии Консульства.

Введение монополизации хлеба государством встречено с доверием и даже сочувственно, но поселяне боятся за судьбу посевов в связи с наездом киргиз с большими стадами скота.

Общая площадь посева предполагается не менее прошлогодней, а в некоторых поселках даже больше, что объясняется увеличением количества рабочих рук, благодаря приехавшим в отпуск солдатам.

Я лишен возможности сообщить точные цифры посева, так как во время моей поездки по поселкам пашни только обрабатывались. Ссуда на обсеменение для многих поселян пришлась кстати.

Желание всех поселков, кроме Калгутона и Чонкура, доставить зерно взамен полученной ссуды на Бурчум как стоящий от них ближе Шарасумэ.

Как видно из описательной части отчета, местная административная власть в поселках представляет разнообразную картину.

В одних эта власть сосредоточена в руках выборного старшины, в других, - у сельского комитета и старосты, в наиболее же маленьких поселках административная власть никем не представлена: имеются только «старшие».

Взаимоотношения между старостами и комитетами и разграничение их функций также не могут быть приведены под один уровень. Там, где староста энергичный и высоко держит свой авторитет, комитет мало проявляет свою инициативу и как бы всю полноту власти 
передает старосте, являясь при нем сельской думой. В других колониях, наоборот, во главе всех общественных дел стоит комитет, а староста лишь исполняет его постановления.

Административною властью на местах пользуются также казаки конвоя консульства. Раньше, когда отношения к киргизам были построены на началах завоевания этого края, когда китайская власть в глазах туземцев аннулировалась и когда самодеятельность крестьян была ничтожная, казаки, благодаря умелому хорошему подбору, пользовались как у туземцев, так и колонистов большим авторитетом.

Теперь же, при представлении гражданам - крестьянам широких прав самоуправления, авторитет казака сохранился только в глазах киргиз, относящихся вообще с уважением к всякому носителю власти. При таком положении роль казака как администратора свелась к передаче распоряжений и указаний консула, который является высшим административным органом подведомственного ему района.

Следственная власть и судебные функции в пределах компетенции мирового судьи сосредоточена по закону в руках консула. На местах эта власть до некоторой степени осуществлялась консульством через уполномоченных лиц, командируемых в поселки. Такими лицами являются офицеры консульского конвоя и Отряда без специальной юридической подготовки и без предоставленного по закону права производить следственные действия. Вся их работа на судебной области сводится лишь к производству дознаний и склонению сторон миром или третейским судом покончить споры, а потому поездки таких лиц не достигают своего назначения, и консулу все равно приходится для производства следствий и решений дел по существу вызывать граждан в Шарасумэ.

До сего времени вопросы, не выходящие из пределов подсудимости русского волостного суда, разрешаются иногда миролюбивым соглашением сторон при участии старосты и членов комитета, чаще же всего спорящие расходятся не получив должного удовлетворения: один в сознании своей правоты, другой - с болью и горечью на сердце.

О разборе дел третейским судом до моего приезда мало было слышно, что вполне понятно, так как граждане поселков характера и значения этого суда не знают. Спор и недоразумения крестьян с туземцами, не выходящие за пределы вопросов, подлежащих, согласно трактатам, совместному разрешению консула и цинсая ${ }^{42}$, находят себе разрешение в единоличном постановлении китайского галдая и в совместных съездах спорящих сторон. На этих съездах дела разрешаются миролюбивым соглашением при участии казака и киргизских цзалынов.

К сожалению, эти «международные» суды по техническим трудностям не носят периодического характера, а собираются случайно, не пользуются должным вниманием русских колонистов.

Из всего сказанного мы видим, что права как отдельных лиц, так и целых обществ не находят себе должной судебной и административной защиты на местах. Если раньше с этим явлением можно было мириться, то теперь с предоставлением крестьянам прав гражданства и свободы и при наличии мирной культурной политики колонизации края в основе общественных и личных отношений как самих колонистов, так и их с киргизами должны быть положены правовые начала и созданы постоянные, компетентные и авторитетные органы. Такими органами должны быть: 1) специальный представитель Консульства с судебно-административными функциями самого Консула - краевой судья, который, имея местопребывание в одном из центральных поселков и периодически совершая поездки по колониям, мог бы со всей тщательностью и соблюдением процессуальных норм и параграфов трактатов исполнять все возложенные на него законом задачи.

2) в каждом поселке необходимо создание выборного народного суда с компетенцией Волостного Суда в России, для которого апелляционной и кассационной инстанцией

\footnotetext{
${ }^{42}$ Цинсай - возможно, цзайсан - глава, начальник племени, рода - см.: Письма Н.Ф. Катанова из Сибири и Восточного Туркестана: Чит. в заседании Ист.-филол. отд. 9 янв. 1890 г. СПб., 1893. С. 19 (15). См. также: Грумм-Гржимайло Г.Е. Западная Монголия и Урянхайский край. Л., 1926. Т. 3. Вып. 1. Антропологический и этнографический очерк этих стран / сост. Г.Е. Грумм-Гржимайло. С. 84 (156).
} 
являлся бы суд краевого судьи. Причем для разрешения дел, где будут затронуты интересы киргиз, к участию в таких народных судах должны быть прилагаемы, в качестве полноправных судей киргизские власти или выборные киргизами как стороной. Краевой же Суд такие смешанные дела должен разрешать совместно с китайским Галдаем или киргизским угурдаем ${ }^{43}$. Органом же административного управления на местах должны сохраниться старосты на ряду с возникшими сельскими комитетами, причем их взаимоотношения, права и обязанности надо преподать для руководства в специальной инструкции.

Только такая судебно-административная реформа поможет колонистам построить свою жизнь на началах права и справедливости и высоко поставит знамя русского гражданина за границей, воспитывая в нем светлое чувство любви к Родине и уважения к туземцам как членам дружественной нам Великой Китайской Республики.

\section{Прапорщик Артиллерии}

\section{Мошкин}

АВП РИ. Ф. 143. Оп. 491. Д. 640. Л. 340-356. Машинописный подлинник. Сопроводительная записка консула Российской Империи в Шарасумэ М. Кузьминского «В Четвертый Политический Отдел Министерства Иностранных Дел» от 16 июня 1917 г. - Л. 339, 357. Сохранена стилистика и орфография документа.

\section{Лumepamypa}

Аблажей Н.Н., Наземцева Е.Н. «То, чего добивалось дореволюционное русское правительство, в 1920-е гг. совершалось стихийно» (к истории заселения Трехречья) // Исторический курьер. 2019. № 4 (6). Статья 5. URL: http://istkurier.ru/data/2019/ISTKURIER-2019-405.pdf (дата обращения: 19.05.2020).

Аргудяева Ю.В. Старообрядцы на Дальнем Востоке России. М.: ИЭА РАН, 2000. 365 с.

Аргудяева Ю.В., Хисамутдинов А.А. Из России через Азию в Америку: русские старообрядцы. Владивосток: Дальнаука, 2013. 428 с.

Воскресенский А.Д. Дипломатическая история русско-китайского Санкт-Петербургского договора 1881 г. М.: ПИМ, 1995. 440 с.

Галиев В.В. Российские консульства в Синьцзяне (конец XIX - начало XX вв.), АлмаАты: Атамура, 2011. 463 с.

Грумм-Гржимайло, Г.Е. Западная Монголия и Урянхайский край. Л., 1926. Т. 3. Вып. 1. Антропологический и этнографический очерк этих стран / сост. Г.Е. Грумм-Гржимайло. 412 с.

Гутин И.Ю. Динамика численности русского населения Синьцзян-Уйгурского автономного района (1949-2000 гг.) // Вестник МГИМО-Университета. 2011. Вып. 3. С. 74-82.

Моисеев В.А. Россия и Китай в Центральной Азии (вторая половина XIX в. - 1917 г.). Барнаул: АзБука, 2003. 346 с.

Письма Н.Ф. Катанова из Сибири и Восточного Туркестана: Чит. в заседании Ист.-филол. отд. 9 янв. 1890 г. СПб.: Тип. Имп. Акад. наук, 1893. 114 с.

Попов А.В. Русская диаспора в Синьцзян-Уйгурском автономном районе Китая // Национальные диаспоры в России и за рубежом в XIX-XX вв.: сб. ст. М., 2001. С. 194-201.

Пржевальский H.M. Четвертое путешествие в Центральной Азии, От Кяхты на истоки Желтой реки, исследование северной окраины Тибета и путь через Лоб-нор по бассейну Тарима. 1-е изд. СПб.: РГО, 1888. 537 с.

Селицкий, И.В. Кульджинские переселенцы пограничной с Китаем полосы: экон.-этногр. очерки и быт. жизнь джаркент. таранчей и дунган. Казань: Типо-лит Ун-та, 1905. 82 с.

Тюркологические исследования. 2018, Т. 1, № 2. 184 с.

\footnotetext{
${ }^{43}$ Киргизский угурдай - представитель власти из местного населения - киргиз (казахов), утверждаемый властями Синьцзяна. Власть была наследственной. Угурдай обладал значительной долей самостоятельности, ему принадлежало право окончательного решения по маловажным проступкам. Подчинялся амбаню (губернатору), высшему представителю маньчжурской администрации, подчиненному непосредственно илийскому цзянцзюню. Амбань сосредотачивал в своих руках исполнительную и судебную ветви власти. Как укурдайства, так и цзангинства назывались по именам возглавлявших их лиц.
} 
Хисамутдинов А.А. В поисках земли обетованной: русские старообрядцы из России через Азию в Америку. Владивосток, 2015. 59 с. URL: https://evols.library.manoa.hawaii.edu/handle/ 10524/48722 С. 22-25 (дата обращения: 03.05.2020).

Цутому Цукадо. Участие в войнах русских старообрядцев в округе Алтай (СиньцзянУйгурский автономный район КНР) // Международные Заволокинские чтения. Рига, 2016. Сб. 4. С. 520-530.

\section{References}

Ablazhei, N.N., Nazemtseva, E.N. (2019). “To, chego dobivalos dorevolyutsionnoe russkoe pravitelstvo, v 1920-e gg. sovershalos stikhiino" (k istorii zaseleniya Trekhrechya) ["What the prerevolutionary Russian government tried to achieve, in the 1920s was done spontaneously" (to the history of the settlement of the Three rivers territory)]. In Istoricheskiy kurier. No. 4 (6), article 5. URL: http://istkurier.ru/data/2019/ISTKURIER-2019-4-05.pdf

Argudyaeva, Yu.V. (2000). Staroobryadtsy na Dalnem Vostoke Rossii [Old Believers in the Russian Far East]. Moscow: IEA RAN. 365 p.

Argudyaeva, Yu.V., Khisamutdinov, A.A. (2013). Iz Rossii cherez Aziyu v Ameriku: russkiye staroobryadtsy [From Russia through Asia to America: Russian Old Believers]. Vladivostok: Dalnauka. 428 p.

Galiev, V.V. (2011). Rossiyskie konsulstva v Sintszyane (konets XIX - nachalo XX vv.) [Russian consulates in Xinjiang (late $19^{\text {th }}$ - early $20^{\text {th }}$ centuries.)]. Alma-Aty: Atamura. $463 \mathrm{p}$.

Grumm-Grzhimailo, G.E. (1926). Zapadnaya Mongoliya i Uryankhaiskiy krai. Tom 3. Vypusk 1. Antropologicheskiy i etnograficheskiy ocherk etikh stran / sostavlen G.E. Grumm-Grzhimailo. [Western Mongolia and the Uryanhai Territory. Vol. 3. Iss. 1. Anthropological and ethnographic essay of these countries / compiled by G.E. Grumm-Grzhimailo]. Leningrad. 412 p.

Gutin, I.Yu. (2011). Dinamika chislennosti russkogo naseleniya Sintszyan-Uygurskogo avtonomnogo rayona (1949-2000 gg.) [Dynamics of the Russian population of the Xinjiang Uygur Autonomous region (1949-2000)]. In Vestnik MGIMO Universiteta. 2011. No. 3. pp. 74-82

Khisamutdinov A.A. (2015). V poiskakh zemli obetovannoy: russkie staroobryadtsy iz Rossii cherez Aziyu v Ameriku [In search of the promised land: Russian old believers from Russia through Asia to America]. URL: https://evols.library.manoa.hawaii.edu/handle/10524/48722 59 p. (date of access: 03.05.2020).

Moiseev, V.A. (2003). Rossiya i Kitay v Tsentralnoy Azii (vtoraya polovina XIX v. - 1917 g.). [Russia and China in Central Asia (second half of the $19^{\text {th }}$ Century -1917 )]. Barnaul: AzBuka. $346 \mathrm{p}$.

(1893). Pisma N.F. Katanova iz Sibiri i Vostochnogo Turkestana: Chit. v Zasedanii Ist.-filol. otd. 9 yanv. 1890 g. [Letters of N.F. Katanov from Siberia and East Turkestan: Reported at a meeting of the Hist.-Phil. Dep. Jan 9, 1890] / [Foreword.: V. Radlov]. St. Petersburg: Tip. Imp. Akad. nauk. 114 p.

Popov A.V. (2001). Russkaya diaspora v Sintszyan-Uygurskom avtonomnom rayone Kitaya [Russian Diaspora in the Xinjiang Uygur Autonomous region of China]. In Natsionalnye diaspory $v$ Rossii i za rubezhom v XIX-XX vv.: sbornik statey. Moscow, pp. 194-201.

Przhevalskiy N.M. (1888). Chetvertoe puteshestvie v Tsentralnoy Azii: Ot Kyakhty na istoki Zheltoy reki, issledovanie severnoy okrainy Tibeta i put cherez Lob-nor po basseinu Tarima [The fourth journey in Central Asia: From Kyakhta to the sources of the Yellow river, exploring the Northern edge of Tibet and the way through the LOB-nor along the Tarim basin]. 1-e izd. St. Petersburg: RGO. 537 p.

Selitskiy, I.V. (1905). Kuldzhinskie pereselentsy pogranichnoy s Kitaem polosy: Ekon.-etnogr. ocherki i byt. zhizn dzharkent. taranchei i dungan [Ghulja immigrants near the Chinese border: Economic and ethnographic sketches and everyday life of Dzharkent Taranchi and Dungans]. Kazan: Tipo-lit Un-ta. 82 p.

Tsutomu Tsukado. Uchastie v voinakh russkikh staroobryadtsev v okruge Altai (SintszyanUigurskiy avtonomnyi raion KNR) [Participation in the wars of Russian Old believers in the Altai 
district (Xinjiang Uygur Autonomous region of China)]. In International Zavolokin readings. Riga, 2016. No. 4, pp. 520-530.

(2018). Tyurkologicheskie issledovaniya [Turkological studies]. 2018. Vol. 1, No. 2. 2018. 184 p. Voskresenskiy, A.D. (1995). Diplomaticheskaya istoriya russko-kitayskogo Sankt-Peterburgskogo dogovora $1881 \mathrm{~g}$. [Diplomatic History of the Russian-Chinese St.Petersburg Treaty of 1881]. Moscow: PIM. 440 p.

Статья поступила в редакцию 21.05.2020 г. 